Tropical Journal of Pharmaceutical Research September 2020; 19 (9): 1919-1926

ISSN: $1596-5996$ (print); 1596-9827 (electronic) (C) Pharmacotherapy Group, Faculty of Pharmacy, University of Benin, Benin City, 300001 Nigeria.

\title{
Antihyperglycemic, antidyslipidemic and antioxidant properties of hydromethanol extract of Eremomastax speciosa leaf in alloxan monohydrate-induced hyperglycemic rats
}

\author{
SO Onoja ${ }^{1 *}$, UO Effiong ${ }^{2}$, BK Chukwuocha², CC Okorie-Kanu ${ }^{3}$, MI Ezeja1, YN \\ $\mathrm{Omeh}^{2}$, AO Anaga ${ }^{4}$ \\ ${ }^{1}$ Department of Veterinary Physiology, Pharmacology, Biochemistry and Animal Health and Production, Michael Okpara \\ University of Agriculture, Umudike, Umuahia, ${ }^{2}$ Department of Biochemistry, Michael Okpara University of Agriculture, Umudike, \\ Umuahia, ${ }^{3}$ Department of Veterinary Pathology, Michael Okpara University of Agriculture, Umudike, Umuahia, Nigeria, \\ ${ }^{4}$ Department of Veterinary Physiology and Pharmacology, Faculty of Veterinary Medicine, University of Nigeria, Nsukka, Nigeria
}

*For correspondence: Email: samonreal@yahoo.com; Tel: +234-8030613032

Sent for review: 1 April 2018

Revised accepted: 25 August 2018

\begin{abstract}
Purpose: To investigate the antihyperglycemic, anti-dyslipidemic and antioxidant properties of hydromethanol extract of Eremomastax speciosa leaf in alloxan monohydrate-induced hyperglycemic rats.

Methods: Hydromethanol extract of Eremomastax speciosa leaf was tested at dose range of 25 to 100 $\mathrm{mg} / \mathrm{kg}$ against vehicle (distilled water) and glibenclamide (2 $\mathrm{mg} / \mathrm{kg}$, reference standard) in alloxaninduced hyperglycemic rats. Gas chromatography mass spectrometry (GC-MS) was employed in the identification of phytoconstituents. The fasting blood glucose (FBG), serum lipid profile, malondialdehyde, catalase and superoxide dismutase levels as well as the histopathology of the pancreas of the animals were evaluated.

Results: The extract $(25 \mathrm{mg} / \mathrm{kg})$ significantly reduced FBG, lipid profile and malondialdehyde levels relative to vehicle treated group but increased the superoxide dismutase and catalase levels and reversed alloxan-induced pancreatic islet cell degeneration. GC-MS analysis showed the presence of 4,5-dimethylthiazole (4.38\%), benzenesulfonic acid, methyl ester (15.62\%), benzenesulfonyl chloride (40.62\%), benzopyran-4-one, 5,7-dihydroxy-2-phenyl- (21.25\%), 2(5H)-furanone, 4-methoxy-5-phenyl(12.50\%), and p-chlorobenzenesulfonyl chloride (5.62\%)

Conclusion: The hypoglycemic effect of the extract validates the folkloric uses of $E$. speciosa leaf in the ethnobotanical care of diabetes mellitus.
\end{abstract}

Keywords: antihyperglycemic, antioxidant, anti-dyslipidemic, Eremomastax speciosa

This is an Open Access article that uses a fund-ing model which does not charge readers or their institutions for access and distributed under the terms of the Creative Commons Attribution License (http://creativecommons.org/licenses/by/4.0) and the Budapest Open Access Initiative (http://www.budapestopenaccessinitiative.org/read), which permit unrestricted use, distribution, and reproduction in any medium, provided the original work is properly credited.

Tropical Journal of Pharmaceutical Research is indexed by Science Citation Index (SciSearch), Scopus, International Pharmaceutical Abstract, Chemical Abstracts, Embase, Index Copernicus, EBSCO, African Index Medicus, JournalSeek, Journal Citation Reports/Science Edition, Directory of Open Access Journals (DOAJ), African Journal Online, Bioline International, Open-J-Gate and Pharmacy Abstracts

\section{INTRODUCTION}

Diabetes mellitus is described as chronic endocrine and/or metabolic disorder usually characterized by insulin deficiency, insulin resistance or a combination of both [1]. The insulin resistance is associated with obesity, aging and reduced physical activities [2]. Insulin 
resistance give rise to hyperglycemia, dyslipidemia, diabetes and its complications [3]. Hyperglycemia inhibits superoxide dismutase and catalase by protein glycation, therefore aggravating free radical generation with resultant increase in lipid peroxidation and oxidative stress [4]. Oxidative stress is incriminated in the progression of diabetes mellitus and its complications; cardiovascular disease, neurological disorder, cancer, nephrotoxicity, liver damage, inflammation etc [5,6]. The most common form of diabetes is type 2 and it constitutes about $90 \%$ of the diabetic patients' population [7]. The treatment strategy for type 2 diabetes involves change of lifestyle (diet and physical exercise), insulin and oral hypoglycemic drug therapy [8]. The limitation of insulin and oral hypoglycemic drugs are the development of some side effects like hypersensitivity reaction, hypoglycemia, lactic acidosis, obesity, sodium retention, osteoporosis etc [9-11]. Despite the side effects of insulin and oral hypoglycemic drugs most diabetic patients from the underdeveloped countries depend on herbal preparations for the management of their health conditions. This has been attributed to poverty, cultural inclination, high cost of treatment and inadequate access to health facilities [12]. Eremomastax speciosa (Acathaceae) commonly called "blood plant" in Cameroon is an erect medicinal plant used in the management of anaemia and stomach disorders [13]. The leaf decoction is used in traditional management of diabetes mellitus in Ikot-Ekwere Akwa-lbom state (oral communication), but this is yet to be reported in scientific literature. The pharmacolocgical activities; antianaemic [14,15], antiulcer [16], antisecretory [17], antimicrobial [14], antifungal [13] and antidiarrhoea [18] have been reported. The purpose of this study was to investigate the antihyperglycemic, antioxidant and anti-dyslipidemic activities of hydromethanol extract of $E$. speciosa leaf on alloxan monohydrate-induced hyperglycemic rats.

\section{EXPERIMENTAL}

\section{Extract preparation}

E. speciosa (aerial parts) were harvested from Itu in Ikot-Ekwere Itam, Akwa-Ibom State, Nigeria and identified by Mr. Okon Etefia. The plant material was chopped, dried at normal environmental temperature $\left(27 \pm 2{ }^{\circ} \mathrm{C}\right)$ for two weeks and ground into coarse powder with electric hammer mill. The coarse powder (410 g) was soaked in $80 \%$ methanol (Sigma Aldrich, USA) for 48 hours. The mixture was shaken gently at 3 hours intervals during this period, after which it was sieved with Whatmann number
1 filter paper. Later, the extract was dried in an oven (Surgifriend Medical, England) at $40{ }^{\circ} \mathrm{C}$ to exhaustively evaporate the methanol leaving a dark-green viscous $E$. speciosa extract (ESE) weighing $136.4 \mathrm{~g}(35.7 \% \mathrm{w} / \mathrm{w})$.

\section{Gas chromatography-mass spectrometry (GC-MS) of ESE}

The GC-MS analysis of ESE was carried out using GCMS-QP2010 PLUS (SHIMADZU, JAPAN) equipped with a DB-5MS column (J \& W Scientific, Folsom, CA) [19]. The compounds were identified by comparing with the available data at National Institute of Standards and Technology mass spectral database.

\section{Animals}

Following approval by the Ethical Committee in University of Nigeria, Nsukka, albino Wistar rats (40) weighing between 110-140 g were obtained from reliable source. The rats were acclimatized for 14 days under ambient temperature of $27 \pm 2$ ${ }^{\circ} \mathrm{C}$ and natural light/dark cycle. They were fasted of food (16 hours) prior to the experiments. The animal house was well ventilated and rats were given standard animal chow and tap water ad libitum.

\section{Acute oral toxicity test}

This was conducted using Up and Down method [20] and dose limit of $2000 \mathrm{mg} / \mathrm{kg}$ [21].

\section{Experimental design}

The induction of diabetes and experimental protocol were conducted as modified by Okwudili et al [22]. Briefly, 30 diabetic rats were randomly separated into 5 groups $(I-V)(n=6)$. The group I received vehicle (distilled water, $5 \mathrm{ml} / \mathrm{kg}$ ) and group II, glibenclamide (German Nigerian Chemist, Nigeria) $2 \mathrm{mg} / \mathrm{kg}$ while groups III-V received ESE at 25, 50 and $100 \mathrm{mg} / \mathrm{kg}$, respectively. ESE and drug were administered per os and FBG levels were determined at 1, 3 and $6 \mathrm{~h}$ after treatment. Thereafter, the rats were dosed once daily for 14 consecutive days. On day 14, the rats were fasted for 16 hours and blood was collected via the median canthus for serum sample preparation and determination of lipid profile. Thereafter, the liver was excised following cervical dislocation. Ten percent liver homogenate in phosphate buffer saline $(\mathrm{pH} 7.0)$ was used for estimation of lipid peroxidation, catalase and superoxide activity. The pancreas was also excised and preserved in $10 \%$ formal saline for histopathologic examination. The 
relative organ weight of kidney, liver and heart were also determined.

\section{Estimation of serum lipid profile}

The serum cholesterol, triacylglycerol and highdensity lipoprotein cholesterol (HDL-C) levels were estimated with commercial assay kits (Randox Laboratory Diagnostics, United Kingdom) according to the manufacturer's procedures. Serum low density lipoprotein cholesterol (LDL-C) was calculated using Friedewald's equation [23]. LDL-C = [cholesterol - $\{\mathrm{HDL}-\mathrm{C}+$ (triacylglycerol/5)\}] where VLDL-C = (triacylglycerol/5) [4].

\section{In vivo antioxidant status}

The determination of lipid peroxidation (LPO) in the liver homogenate was done by thiobarbituric acid reactive substances (TBARS) [24], assay of superoxide dismutase [25] and catalase [26].

\section{Histopathology}

The tissue sections were prepared according to the methods used by Ezeja et al [1]. Photomicrographs were captured at 400 magnifications with digital microscope (Olympus Scientific Equipment, USA).

\section{Data analysis}

The data were presented as mean \pm standard error of mean (SEM) and analysed using ANOVA), and variant means were separated by least significant difference (LSD) test with SPSS version 21.0. The $p$ values $<0.05$ were statistically significant.

\section{RESULTS}

\section{Acute toxicity study}

The ESE produced no sign of toxicity and mortality at $2000 \mathrm{mg} / \mathrm{kg}$ (LD 50 of ESE was >2000 $\mathrm{mg} / \mathrm{kg}$ ).

\section{Chemical composition of ESE as identified by the GC-MS}

A total of six (6) compounds corresponding to the 6 peaks in the GC-MS chromatogram were identified (Figure 1). These were $2(5 \mathrm{H})$-furanone, 4-methoxy-5-phenyl- (12.50\%), benzenesulfonic acid, methyl ester (15.62\%), benzenesulfonyl chloride (40.62\%), benzopyran-4-one, 5,7dihydroxy-2-phenyl- (21.25\%), 4,5-dimethylthiazole $(4.38 \%)$ and p-chlorobenzenesulfonyl chloride $(5.62 \%)$ (Table 1$)$. Molecular structures of the compounds are presented in Figure 2.

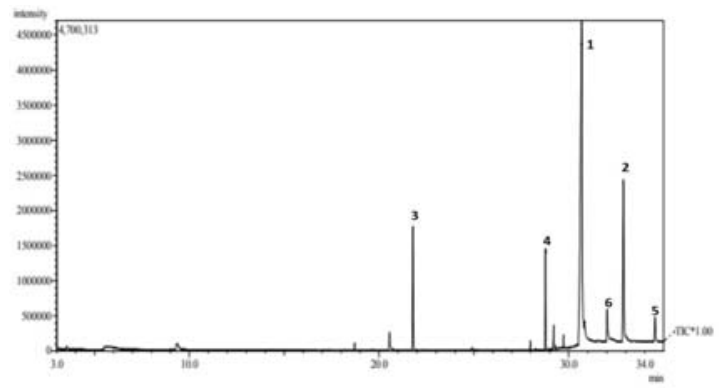

Figure 1. GC-MS chromatogram of E. speciosa extract. Legend: 1 = benzenesulfonyl chloride, 2 = benzopyran-4-one, 5,7-dihydroxy-2-phenyl-, $\quad 3=$ benzenesulfonic acid, methyl ester, $4=2(5 \mathrm{H})$ furanone, 4-methoxy-5-phenyl-, $\quad 5=4,5-$ dimethylthiazole, $\mathbf{6}=\mathrm{p}$-chlorobenzenesulfonyl chloride

\section{Acute effects of ESE on FBG}

Glibenclamide and ESE $25 \mathrm{mg} / \mathrm{kg}$ increased $(\mathrm{p}<$ $0.05)$ percentage reduction in FBG of treated rats relative to vehicle treated rats. ESE also produced non-dose-dependent antihyperglycemic effect (Figure 3).

\section{Sub-acute effects of ESE on FBG}

The FBG of the various treatment groups did not vary significantly $(p>0.05)$ on day 0 while on day 7 and 14 the FBG of glibenclamide and ESE treated rats were within the normal range $(<120$ $\mathrm{mg} / \mathrm{dl})$ and significantly lower $(\mathrm{p}<0.05)$ than those of the vehicle treated rats $(>126 \mathrm{mg} / \mathrm{dl}$ ) (Table 2).

Table 1: Chemical composition of E. speciosa extract as identified by the GC-MS

\begin{tabular}{llllll}
\hline S/N & $\begin{array}{l}\text { Retention } \\
\text { time (min) }\end{array}$ & $\%$ & $\begin{array}{l}\text { Molecular } \\
\text { weight }(\mathbf{g})\end{array}$ & $\begin{array}{l}\text { Molecular } \\
\text { formular }\end{array}$ & Chemical name \\
\hline 1 & 30.60 & 40.63 & 176 & $\mathrm{C}_{6} \mathrm{H}_{5} \mathrm{ClO}_{2} \mathrm{~S}$ & Benzenesulfonyl chloride \\
2 & 33.00 & 21.25 & 254 & $\mathrm{C}_{15} \mathrm{H}_{10} \mathrm{O}_{4}$ & Benzopyran-4-one, 5,7-dihydroxy-2-phenyl- \\
3 & 21.80 & 15.63 & 172 & $\mathrm{C}_{7} \mathrm{H}_{8} \mathrm{O}_{3} \mathrm{~S}$ & Benzenesulfonic acid, methyl ester \\
4 & 28.80 & 12.50 & 190 & $\mathrm{C}_{11} \mathrm{H}_{10} \mathrm{O}_{3}$ & $2(5 \mathrm{H})$-Furanone, 4-methoxy-5-phenyl- \\
5 & 34.50 & 4.38 & 113 & $\mathrm{C}_{5} \mathrm{H}_{7} \mathrm{NS}$ & 4,5 -Dimethylthiazole \\
6 & 32.00 & 5.63 & 210 & $\mathrm{C}_{6} \mathrm{H}_{4} \mathrm{Cl}_{2} \mathrm{O}_{2} \mathrm{~S}$ & p-Chlorobenzenesulfonyl chloride \\
\hline
\end{tabular}

Legend: $\%=$ percentage composition 
<smiles>O=S(=O)(Cl)c1ccccc1</smiles>

Benzenesulfonyl chloride<smiles>COC1=CC(=O)OC1c1ccccc1</smiles>

2(5H) - Furanone,- 4-methoxy-5-phen!<smiles>O=c1cc(-c2ccccc2)oc2cc(O)cc(O)c12</smiles>

Benzopyran - 4 - one, 5,7 -dihydroxy - 2 - phenyl Benzosulfonic acid, methyl ester<smiles>Cc1ncsc1C</smiles>

4,5 - dimethylthiazole $\quad p$-Chlorobenzenesulfonyl chloride<smiles>COS(=O)(=O)c1ccccc1</smiles><smiles>O=S(=O)(Cl)c1ccc(Cl)cc1</smiles>

Figure 2: Chemical structures of the compounds identified by the GC-MS analysis of $E$. speciosa extract

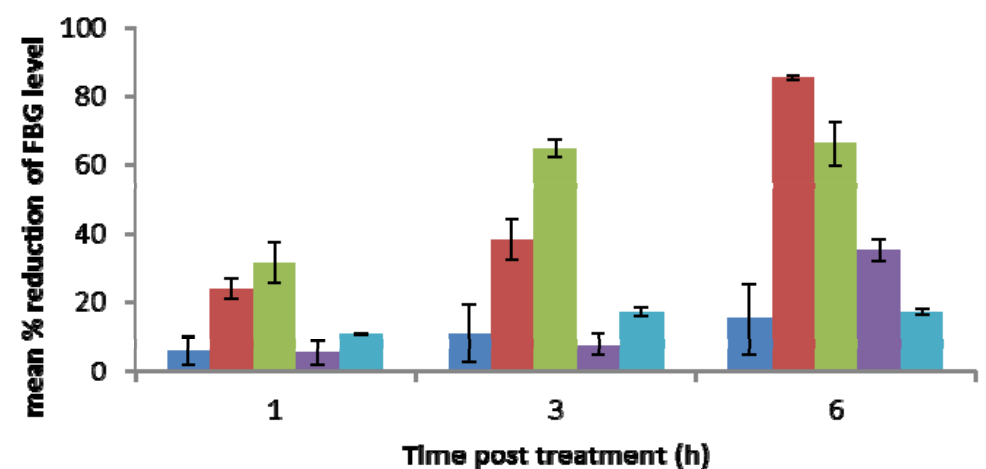

\section{Distilled water $5 \mathrm{ml} / \mathrm{kg}$}

- Glibenclamide

ESE $25 \mathrm{mg} / \mathrm{kg}$

- ESE $50 \mathrm{mg} / \mathrm{kg}$

ESE $100 \mathrm{mg} / \mathrm{kg}$

Figure 3: Acute effects of E. speciosa extract on fasting blood glucose

\section{Effect of ESE on lipid profile}

The ESE significantly reduced $(p<0.05)$ serum cholesterol, triacylglycerol, VLDL-C, LDL-C and significantly increased $(p<0.05)$ HDL-C levels in the treated group relative to vehicle treated group. Glibenclamide produced increased $(p<$ 0.05 ) cholesterol and HDL-C levels but did not cause $(p>0.05)$ change in triacylglycerol, VLDL$\mathrm{C}$ and LDL-C levels relative to distilled water treated rats (Table 3$)$.

\section{In vivo antioxidant activities of ESE}

Malondialdehyde levels of ESE and glibenclamide treated rats were low $(P<0.05)$ relative to vehicle treated rats (Table 4). The ESE $(25 \mathrm{mg} / \mathrm{kg})$ and glibenclamide treatment increased $(P<0.05)$ activity of catalase, while ESE (50 and $100 \mathrm{mg} / \mathrm{kg})$ decreased $(P<0.05)$ the activities of catalase in the treated rats relative to vehicle treated rats (Table 4). Also, ESE $(25 \mathrm{mg} / \mathrm{kg})$ and glibenclamide elevated $(P<$ 0.05 ) activity of superoxide dismutase in treated rats relative to vehicle treated rats (Table 4).

Table 2: Sub-acute effects of $E$. speciosa extract on fasting blood glucose

\begin{tabular}{|c|c|c|c|}
\hline \multirow[b]{2}{*}{ Treatment } & \multicolumn{3}{|c|}{ Fasting blood glucose \pm SEM (mg/dl) } \\
\hline & Day 0 & Day 7 & Day 14 \\
\hline Distilled water $5 \mathrm{ml} / \mathrm{kg}$ & $467.75 \pm 113.44$ & $206.67 \pm 47.88$ & $148.00 \pm 33.45$ \\
\hline Glibenclamide $2 \mathrm{mg} / \mathrm{kg}$ & $326.75 \pm 16.72$ & $97.50 \pm 10.17^{*}$ & $73.25 \pm 3.71^{*}$ \\
\hline ESE $25 \mathrm{mg} / \mathrm{kg}$ & $354.50 \pm 50.02$ & $94.00 \pm 5.99^{*}$ & $75.40 \pm 2.94^{*}$ \\
\hline ESE $50 \mathrm{mg} / \mathrm{kg}$ & $409.75 \pm 101.08$ & $74.00 \pm 8.98^{*}$ & $82.60 \pm 6.10^{*}$ \\
\hline ESE $100 \mathrm{mg} / \mathrm{kg}$ & $360.00 \pm 6.35$ & $112.20 \pm 17.96^{*}$ & $71.20 \pm 6.21^{*}$ \\
\hline
\end{tabular}

${ }^{*} \mathrm{p}<0.05$ relative to vehicle treated rats. ESE $=$ Eremomastax speciosa extract, SEM $=$ standard error of mean 
Table 3: Effects of E. speciosa extract on lipid profile

\begin{tabular}{llllll}
\hline Treatment & $\begin{array}{l}\text { Cholesterol } \\
\text { (mg/dl) }\end{array}$ & $\begin{array}{l}\text { Triacylglycerol } \\
\text { (mg/dl) }\end{array}$ & $\begin{array}{l}\text { VLDL-C } \\
\text { (mg/dl) }\end{array}$ & $\begin{array}{l}\text { HDL-C } \\
\text { (mg/dl) }\end{array}$ & LDL-C (mg/dl) \\
\hline Distilled water 5 ml/kg & $45.55 \pm 0.72$ & $30.82 \pm 6.54$ & $6.16 \pm 1.31$ & $6.98 \pm 0.32$ & $32.40 \pm 2.15$ \\
Glibenclamide 2 mg/kg & $60.07 \pm 8.38^{*}$ & $39.51 \pm 17.58$ & $7.90 \pm 3.51$ & $21.95 \pm 0.63^{*}$ & $30.22 \pm 6.19$ \\
ESE $25 \mathrm{mg} / \mathrm{kg}$ & $48.19 \pm 3.26$ & $20.54 \pm 7.05$ & $4.11 \pm 1.41$ & $16.96 \pm 3.20^{*}$ & $27.12 \pm 3.15$ \\
ESE $50 \mathrm{mg} / \mathrm{kg}$ & $39.61 \pm 1.25^{*}$ & $15.01 \pm 1.32^{*}$ & $3.00 \pm 0.26^{*}$ & $18.45 \pm 2.07^{*}$ & $18.15 \pm 0.66^{*}$ \\
ESE $100 \mathrm{mg} / \mathrm{kg}$ & $38.29 \pm 3.26^{*}$ & $6.32 \pm 1.00^{*}$ & $1.26 \pm 1.0^{*}$ & $14.96 \pm 1.09^{*}$ & $22.06 \pm 2.34^{*}$
\end{tabular}

${ }^{*} \mathrm{P}<0.05$ relative to vehicle treated rats. ESE = Eremomastax speciosa extract; VLDL-C = very low-density lipoprotein cholesterol; HDL-C = high density lipoprotein cholesterol; LDL-C = low density lipoprotein cholesterol

Table 4: Effect of E. speciosa extract on some in vivo antioxidant markers

\begin{tabular}{llll}
\hline Treatment & $\begin{array}{l}\text { malondialdehyde } \\
\text { (nanomole/g protein) }\end{array}$ & $\begin{array}{l}\text { Catalase (micromole/g } \\
\text { protein) }\end{array}$ & $\begin{array}{l}\text { superoxide dismutase } \\
\text { (U/g protein) }\end{array}$ \\
\hline Distilled water (vehicle) $5 \mathrm{ml} / \mathrm{kg}$ & $442.62 \pm 98.59$ & $73.49 \pm 15.59$ & $11.68 \pm 0.22$ \\
Glibenclamide $2 \mathrm{mg} / \mathrm{kg}$ & $275.96 \pm 12.25^{*}$ & $619.57 \pm 95.58^{*}$ & $13.94 \pm 1.98^{*}$ \\
ESE $25 \mathrm{mg} / \mathrm{kg}$ & $161.74 \pm 25.51^{*}$ & $146.24 \pm 16.44^{*}$ & $14.57 \pm 0.70^{*}$ \\
ESE $50 \mathrm{mg} / \mathrm{kg}$ & $273.16 \pm 44.46^{*}$ & $55.85 \pm 6.12^{*}$ & $12.39 \pm 0.87$ \\
ESE $100 \mathrm{mg} / \mathrm{kg}$ & $259.77 \pm 17.58^{*}$ & $39.03 \pm 7.46^{*}$ & $8.86 \pm 0.83^{*}$ \\
\hline
\end{tabular}

${ }^{*} \mathrm{p}<0.05$ relative to vehicle treated rats. ESE $=$ Eremomastax speciosa extract

Table 5: Effect of ESE on mean body weights

\begin{tabular}{llll}
\hline & \multicolumn{2}{l}{ Body weight in gram \pm SEM (weight gain \%) } & DAY 14 \\
Treatment & DAY 0 & DAY 7 & $98.33 \pm 12.36(-2.06)$ \\
\hline Distilled water (vehicle) $5 \mathrm{ml} / \mathrm{kg}$ & $100.40 \pm 3.06$ & $95.70 \pm 9.84(-4.68)$ & $92.00 \pm 6.57(8.30)$ \\
Glibenclamide 2 $\mathrm{mg} / \mathrm{kg}$ & $84.95 \pm 4.35^{*}$ & $90.25 \pm 6.22(6.21)$ & $109.22 \pm 5.18(5.71)$ \\
ESE $25 \mathrm{mg} / \mathrm{kg}$ & $103.33 \pm 3.70$ & $106.20 \pm 5.04(2.78)$ & $106.26 \pm 3.64(-7.20)$ \\
ESE $50 \mathrm{mg} / \mathrm{kg}$ & $114.50 \pm 1.34^{*}$ & $105.00 \pm 3.18(-8.29)$ & $94.74 \pm 5.21(-4.54)$ \\
ESE $100 \mathrm{mg} / \mathrm{kg}$ & $99.25 \pm 0.43$ & $96.16 \pm 6.34(-3.11)$ & \\
\hline${ }^{*} \mathrm{p}<0.05$ relative to vehicle treated rats. ESE = Eremomastax speciosa extract; SEM = standard error of mean
\end{tabular}

Table 6: The effects of ESE on relative organ weight

\begin{tabular}{llll}
\hline \multirow{2}{*}{ Treatment } & \multicolumn{2}{l}{ Relative organ weight (\%) } & heart \\
\hline Distilled water (vehicle) $5 \mathrm{ml} / \mathrm{kg}$ & $1.23 \pm 0.03$ & liver & $0.55 \pm 0.04$ \\
Glibenclamide $2 \mathrm{mg} / \mathrm{kg}$ & $1.09 \pm 0.05^{*}$ & $5.45 \pm 0.32$ & $0.47 \pm 0.03^{*}$ \\
ESE $25 \mathrm{mg} / \mathrm{kg}$ & $0.95 \pm 0.07^{*}$ & $3.06 \pm 0.10$ & $0.47 \pm 0.02^{*}$ \\
ESE $50 \mathrm{mg} / \mathrm{kg}$ & $0.97 \pm 0.02^{*}$ & $4.67 \pm 0.20^{*}$ & $0.47 \pm 0.01^{*}$ \\
ESE $100 \mathrm{mg} / \mathrm{kg}$ & $1.16 \pm 0.01$ & $5.01 \pm 0.05$ & $0.59 \pm 0.02$ \\
\hline
\end{tabular}

${ }^{*} \mathrm{p}<0.05$ relative to vehicle treated rats. ESE $=$ Eremomastax speciosa extract

\section{Effect of ESE on body weights (g)}

The vehicle, ESE 50 and $100 \mathrm{mg} / \mathrm{kg}$ treated groups had a persistent weight loss throughout the period of experiment relative to day 0 while the groups treated with glibenclamide and ESE $25 \mathrm{mg} / \mathrm{kg}$ had time-dependent weight gain relative to day 0 (Table 5 ).

\section{Effects of ESE on relative organ weight}

Glibenclamide, ESE 25 and $50 \mathrm{mg} / \mathrm{kg}$ reduced ( $p$ $<0.05$ ) the ROW of liver, kidney and heart of treated rats relative to vehicle treated rats (Table $6)$.

\section{Histopathology}

The vehicle treated group showed fatty infiltration and no visible pancreatic islets. Glibenclamide and ESE $(25,50$ and $50 \mathrm{mg} / \mathrm{kg})$ treated groups showed pancreatic islet cells without fatty infiltration. of ESE With 25 and $50 \mathrm{mg} / \mathrm{kg}$ of ESE, the islet cells were numerous and had evidence of cell regeneration (Figure 4). 


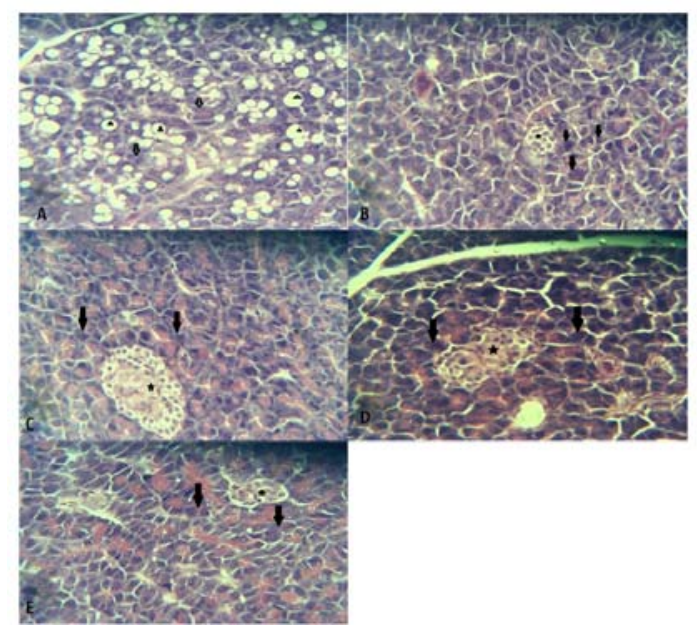

Figure 4: Photomicrograph sections $(H \& E \times 400)$ of pancreas. Star $=$ pancreatic islets; arrow $=$ Acinar cell; Triangle $=$ fat cells; Figure $4 \mathbf{A}, \mathrm{A}$, islet cells of rats treated with distilled water (vehicle) $5 \mathrm{ml} / \mathrm{kg}$; B, islet cells of rats treated with glibenclamide $2 \mathrm{mg} / \mathrm{kg}$; C, islet cells of rats treated with ESE $25 \mathrm{mg} / \mathrm{kg}$; $\mathbf{D}$, islets cells of rats treated with ESE $50 \mathrm{mg} / \mathrm{kg}$; E, islet cells of rats treated with ESE $100 \mathrm{mg} / \mathrm{kg}$.

\section{DISCUSSION}

The hydromethanol extract of $E$. speciosa had $\mathrm{LD}_{50}$ greater than $2000 \mathrm{mg} / \mathrm{kg}$ and elicited hypoglycemic, antidyslipidemic and antioxidant properties as well as reversed pancreatic islet cell degeneration in alloxan-induced hyperglycemic rats. GC-MS of ESE identified 6 bioactive compounds. The observed hypoglycemic, antidyslipidemic and antioxidant activities of $E$. speciosa may be related to 5,7-dihydroxy-2phenyl-benzopyran-4-one (chrysin) [27].

Usually, alloxan treatment cause islet cell degeneration and fatty infiltration of the pancreas (Figure 4) with resultant hyperglycaemia and dyslipidemia which characterize diabetes mellitus [28]. Alloxan structurally (molecular shape) resemble glucose and transported into the betacell of pancreatic islet by Glut-2 glucose transporter in plasma membrane as glucose analogue and accumulate in cytosol where it impairs glucose-stimulated insulin secretion via deactivation of glucokinase [29]. The compound also generates free radicals through cyclic reaction of dialuric acid which leads to plasma membrane damage and necrosis [30].

Chrysin is present in the leaves of the genus, Oroxylum, Chamomille and Passiflora [31]. Its antidiabetic, aromatase inhibitory and antioxidant effects have been reported [27]. Antidiabetic activity of chrysin is via the impaired function of 11-hydroxysteroid dehydrogenase type 1, which leads to reduced cortisol elaboration and increased insulin action [32]. The observed antihyperglycemic activity of $E$. speciosa may be mediated through enhanced insulin sensitivity [33]. ESE caused regeneration of pancreatic islet cells damaged by alloxan (Figure 4) which may be due to inhibition of spontaneous generation of free radical from the reduced form of alloxan, dialuric acid [34]. Antioxidants, especially catalase and superoxide dismutase, can inhibit pancreatic toxicity of alloxan [35]. The extract (25 $\mathrm{mg} / \mathrm{kg}$ ) increased $(p<0.05)$ activities of catalase and superoxide dismutase in treated group. This suggests that antihyperglycemic activity of ESE can be linked to its antioxidant activity [36]. Eremomastax speciosa also, reduced $(p<0.05)$ malondialdehyde equivalent in the treated rats. Malondialdehyde, product of lipid peroxidation, causes DNA fragmentation and plasma membrane damage which will lead to cell death $[6,37]$. The decrease in the level of malondialdehyde suggests that ESE inhibits lipid peroxidation and thus may prevent development of cardiovascular disease [38]. E. speciosa decreased $(p<0.05)$ serum triacylglycerol, LDL-C and elevated HDL-C levels in the treated groups. This suggests that the extract can ameliorate the dyslipidemia which characterizes diabetes mellitus and prevent vascular complications of diabetes [39]. The mechanism of the hypolipidemic effect has not been established but could be via the inhibition of cholesterol absorption, increased expression of LDL-C receptor, increased fecal bile acid excretion and inhibition of HMG-CoA reductase [40].

Alloxan induced diabetes is usually characterized by weight loss due to muscle wasting as a result of negative energy balance and dehydration due to polyuria [41]. The extract $(25 \mathrm{mg} / \mathrm{kg})$ and glibenclamide treatment produced timedependent weight gain in treated rats groups suggesting that the extract may have ameliorated the muscle wasting and polyuria as well as corrected the tissue toxicity which characterizes alloxan treatment as a result of its conversion to butylalloxan [29]. At doses beyond $50 \mathrm{mg} / \mathrm{kg}$, the decrease in the pharmacological activities of $E$. speciosa extract may be as a result of receptor site saturation and inhibition [42].

\section{CONCLUSION}

The results of this study have shown that the hydromethanol extract of Eremomastax speciosa possesses significant antidiabetic, antidyslipidemic and antioxidant properties. This study therefore validates the use of $E$. speciosa leaf in diabetes mellitus treatment. 


\section{DECLARATIONS}

\section{Acknowledgement}

The authors are grateful to Mr. Okon Etefia, a Pharmacognocist in the Department of Pharmacology/Natural Medicine, University of Uyo, Akwa Ibom state, Nigeria for identification of the plant sample. We are grateful to Dr CBC Ikpa for reading the GC-MS spectra and drawing of the molecular structures of the compounds.

\section{Conflict of interest}

No conflict of interest is associated with this work.

\section{Contribution of authors}

We declare that this work was done by the authors named in this article and all liabilities pertaining to claims relating to the content of this article will be borne by the authors.

\section{Open Access}

This is an Open Access article that uses a funding model which does not charge readers or their institutions for access and distributed under the terms of the Creative Commons Attribution License (http://creativecommons.org/licenses/by/ 4.0) and the Budapest Open Access Initiative (http://www.budapestopenaccessinitiative.org/rea d), which permit unrestricted use, distribution, and reproduction in any medium, provided the original work is properly credited.

\section{REFERENCES}

1. Ezeja MI, Anaga AO, Asuzu IU. Antidiabetic, antilipidemic, and antioxidant activities of Gouania longipetala methanol leaf extract in alloxan-induced diabetic rats. Pharm Biol 2015; 53:605-614.

2. Zheng $T$, Shu G, Yang Z, Mo S, Zhao Y, Mei Z. Antidiabetic effect of total saponins from Entada phaseoloides (L.) Merr. in type 2 diabetic rats. J Ethnopharmacol 2012; 139:814-821.

3. Arulmozhi DK, Kurian R, Veeranjaneyulu A, Bodhankar SL. Antidiabetic and antihyperlipidemic effects of Myristica fragrans in animal models. Pharm Biol 2007; 45:64-68.

4. Bhandari U, Chaudhari HS, Khanna G, Najmi AK. Antidiabetic effects of Embelia ribes extract in high fat diet and low dose streptozotocin-induced type 2 diabetic rats. Front Life Sci 2013;7(3-4):186-196.

5. Jarald EE, Joshi SB, Jain DC. Antidiabetic activity of extracts and fraction of Zizyphus mauritiana. Pharm Biol 2009; 47:328-334.
6. Panda SP, Haldar PK, Bera S, Adhikary S, Kandar CC. Antidiabetic and antioxidant activity of Swietenia mahagoni in streptozotocin-induced diabetic rats. Pharm Biol 2010; 48:974-979.

7. Sheth JJ. Diabetes, microalbuminuria and hypertension. Clin Exp Hypertens 1999; 21:61-68.

8. Onoja SO, Anaga AO. Bioassay-guided fractionation, antidiabetic and antioxidant properties of the methanol leaf extract of Helianthus annuus. International Journal of Pharmacognosy and Phytochemical Research 2015:7;340-346.

9. Bösenberg $L H$, van Zyl DG. The mechanism of action of oral antidiabetic drugs: $A$ review of recent literature. Journal of Endocrinology, Metabolism and Diabetes of South Africa 2008;13:80-88.

10. DeFronzo RA. Pharmacologic therapy for type 2 diabetes mellitus. Ann Intern Med 2000; 133:73-74.

11. Sussman M, Sierra JA, Garg S, Bode B, Friedman M, Gill $M$, Kaufman F, Vigersky R, Menzin J. Economic impact of hypoglycemia among insulin-treated patients with diabetes. J Med Econ 2016. DOI: 10.1080/13696998.2016.1201090

12. Sofowora A. Medicinal plants and traditional medicine in Africa (3rd edition). Nigeria: Spectrum Books Limited; 2008. $148 p$.

13. Mouokeu RS, Kuenemo SM, Njateng GSS, Kamtchueng MO, Fonkeng LS, Kuiate JR. Activity of methanol/methylene extract mixtures from Monodora myristica (Gaertn), Xylopia aethiopica and Eremomastax speciosa (Hochst.) against Candida albicans. Pharmacologia 2015; 6:430-437.

14. Okokon JE, Antia BS, Udoh AE, Akpan MM. Antianaemic and antimicrobial activity of Eremomastax speciosa. Journal of Pharmacology and Toxicology 2007; 2:196199.

15. Iba IU, Etuk EU, Akpanabiatu MI, Item E, Ekong IN. Anti anaemic and nephrotoxic effect of ethanolic extract Eremomastax speciosa. Merit Research Journal of Medicine and Medical Sciences 2015; 3:10-12.

16. Tan PV, Nditafon NG, Yewah MP, Dimo T, Ayafor FJ. Eremomastax speciosa: effects of leaf aqueous extract on ulcer formation and gastric secretion in rats. $\mathrm{J}$ Ethnopharmacol 1996; 54:139-142.

17. Amang AP, Paul VT, Nkwengoua $E$, Nyasse $B$. Antisecretory action of the extract of the aerial parts of Eremomastaxspeciosa (Acanthaceae). AdvPharmacol Sci. 2014: Article ID 323470, 10 pages http://dx.doi.org/10.1155/2014/323470

18. Oben JE, Assi SE, Agbor GA, Musoro DF. Effect of Eremomastax speciosa on experimental diarrhea. Afr $\mathrm{J}$ Tradit Complement Altern Med 2006; 3:95-100.

19. Hamza LF, Kamal SA, Hameed IH. Determination of metabolites products by Penicillium expansum and evaluating antimicrobial activity. J Pharmacognosy Phytother 2015;7(9):194-220.

20. OECD. Guidelines for the testing of chemicals, acute oral toxicity - up-and down- procedure, no. 425, Adopted 3 October 2008.

Trop J Pharm Res, September 2020; 19(9): 1925 
21. Onoja SO, Ezeja MI, Omeh YN, Onwukwe BC. Antioxidant, anti-inflammatory and antinociceptive activities of methanolic extract of Justicia secunda Vahl leaf. Alex J Med 2017;53(3):207-213.

22. Okwudili OS, Chimaobi NG, Ikechukwu EM, Ndukaku OY. Antidiabetic and in vitro antioxidant effects of hydromethanol extract of Paullinia pinnata root bark in alloxan-induced diabetic rat. J Complement Integr Med 2018;15(2). DOI: https://doi.org/10.1515/jcim-20150017.

23. Friedewald WT, Levy RI, Fredrickson DS. Estimation of the concentration of low-density lipoprotein cholesterol in plasma, without use of the preparative ultracentrifuge. Clin Chem 1972; 18:499-502.

24. Draper HH, Hadley M. Malondiadehyde determination as index of lipid peroxidation. Methods Enzymol 1990; 186:421-431.

25. Xin Z, Waterman, DF, Henken RM, Harmon RJ. Effect of copper status on neutrophil function, superoxide dismutase and copper distribution in steers. J Diary Sci 1991;74: 3078-3092.

26. Atawodi SE. Evaluation of the hypoglycaemic, hypolipidemic and antioxidant effects of methanolic extract of "ata-ofa" polyherbal tea (A-polyherbal) in alloxan-induced diabetic rats. Drug Invention Today 2011; 3:270-276.

27. Samarghandian S, Azimi-Nezhad M, Samini F, Farkhondeh T. Chrysin treatment improves diabetes and its complications in liver, brain, and pancreas in streptozotocin-induced diabetic rats. Can J Physiol Pharmacol 2016;94(4):388-393.

28. Seufert J. A fixed-dose combination of pioglitazone and metformin: a promising alternative in metabolic control. Curr Med Res Opin 2006; 22: S39-S48.

29. Elsner M, Tiedge M, Guldbakke B, Munday R, Lenzen S. Relative importance of the Glut2 transporter for pancreatic beta-cell toxicity of alloxan. Diabetologia 2002; 45:1542-1549.

30. Brömme HT, Mörke W, Peschke D, Ebelt H. scavenging effects of melatonin on hydroxyl radical generated by alloxan. J Pineal Res 2000; 29:201-208.

31. Ramírez-Espinosa JJ, Saldaña-Ríos J, García-Jiménez $S$, Villalobos-Molina $R$, Ávila-Villarreal $G$, RodríguezOcampo AN, Bernal-Fernández G, Estrada-Soto S. Chrysin Induces Antidiabetic, Antidyslipidemic and AntiInflammatory Effects in Athymic Nude Diabetic Mice. Molecules 2017;23(1):
32. Torres-Piedra $M$, Ortiz-Andrade $R$, Villalobos-Molina $R$, Singh N, Medina-Franco JL, Webster SP, Binnie M, Navarrete-Vázquez Ç, Estrada-Soto S. A comparative study of flavonoid analogues on streptozotocinnicotinamide induced diabetic rats: Quercetin as a potential antidiabetic agent acting via 11-betahydroxysteroid dehydrogenase type 1 inhibition. Eur $\mathrm{J}$ Med Chem 2010; 45:2606-2612.

33. Manukumar HM, Kumar JS, Chandrashekar B, Raghava S, Umesha S. Evidences for diabetes and insulin mimetic activity of medicinal plants: present status and future prospects. Crit Rev Food Sci Nutr 2016. http://dx.doi.org/10.1080/10408398.2016.1143446

34. Rosso JA, Astorga MA, Martire DO, Gonzalez MC. Alloxan-dialuric acid cycling: a complex redox mechanism. Free Radic Res 2009; 43:93-99.

35. Rohilla A, Ali S. Alloxan Induced Diabetes: Mechanisms and Effects. International Journal of Research in Pharmaceutical and Biomedical Sciences 2012; 3:819823.

36. Johnson LA, Maeda N. Macrovascular complications of diabetes in atherosclerosis prone mice. Expert Rev Endocrinol Metab 2010; 5:89-98.

37. Mossanda KS, Bolajoko EB, Moropane M, Adeniyi F, Akinosun $O$, Fasanmade A. Antioxidant and oxidative stress status in type 2 diabetes and diabetic foot ulcer. Journal of Endocrinology, Metabolism and Diabetes of South Africa. 2008; 13:58-63.

38. Candido R, Bernardi S, Allen TJ. Linking diabetes and atherosclerosis. Expert Rev Endocrinol Metab 2009; 4:603-624.

39. Farnier M. An evaluation of alirocumab for the treatment of hypercholesterolemia. Expert Rev Cardiovasc Ther 2015; 13:1307-1323.

40. Singh SV, Shrivastava A, Jyotshna UC, Singh SC, Shanker K, Saxena JK, Bhatia G, Pal A. A mechanismbased pharmacological evaluation of efficacy of Flacourtia indica in management of dyslipidemia and oxidative stress in hyperlipidemic rats. J Basic Clin Physiol Pharmacol 2016; 27:121-129.

41. Jain S, Bhatia G, Barik R, Kumar P, Jain A, Dixit VK. Antidiabetic activity of Paspalum scrobiculatum Linn. in alloxan induced diabetic rats. J Ethnopharmacol 2010; 127:325-328.

42. Evans WC. Trease and Evans Pharmacognosy 16th ed. Edinburgh: W. B. saunders Elsevier; 2009. 58-302. 